\title{
Branding Produk UMKM Kampung Wisata Bisnis Tegal Waru melalui Reputasi Merek dan Basis Informasi Teknologi
}

\author{
Endang Purwaningsih ${ }^{1}$, Suhaeri ${ }^{2}$, Evie Rachmawati Nur Ariyanti ${ }^{1}$ \\ ${ }^{1}$ Fakultas Hukum, ${ }^{2}$ Fakultas Teknik Informatika, Universitas YARSI \\ Menara Yarsi, JI. Letjend Suprapto Kav.13, DKI Jakarta, 10510, Indonesia
}

\author{
ARTICLE INFO: \\ Received: 2019-05-24 \\ Revised: $2019-10-19$ \\ Accepted: 2020-01-18 \\ Keywords: \\ Brand reputation; \\ Information technology; \\ Product branding
}

\begin{abstract}
The objectives of this program are increasing the competence of producers in the product business link by facilitating the formation of legal entities, legal protection of brands expanding internet marketing networks (online), and improving marketing management competencies. The method of approach is to conduct training and mentoring continuously until it is independent. The results of this activity Tegal Waru SMEs want to optimize the role of BUMDES, so there is no need to create an UMKM association, want to have a trademark and compare with e commerce that has been provided by the team. It is expected that turnover will increase, more than 20 percent. In the previous year's mono PKM the turnover had increased by 20 percent, so in 2019-2020 it was targeted to increase by 25 percent.
\end{abstract}

(C) 2020 Published by University of Merdeka Malang. This is an open access article distributed under the CC BY-SA 4.0 license (https://creativecommons.org/licenses/by-sa/4.0/)

How to cite: Purwaningsih, E., Suhaeri, \& Ariyanti, E. R. N. (2020). Branding Produk UMKM Kampung Wisata Bisnis Tegal Waru melalui Reputasi Merek dan Basis Informasi Teknologi. Abdimas: Jurnal Pengabdian Masyarakat Universitas Merdeka Malang, 5(1), 60-69. https://doi.org/10.26905/abdimas.v5i1.3392

\section{PENDAHULUAN}

Kampung wisata bisnis saat ini makin diminati trend bisnis UMKM, sehingga di daerah Bogor pun tumbuh beberapa kampung wisata bisnis, tidak terkecuali Kampung Wisata Bisnis Tegal Waru. Kampung ini telah menjadi subyek kegiatan pengabdian kepada masyarakat pengusul dalam dua tahun terakhir ini, dan berdasarkan hasil kegiatan pengabdian kepada masyarakat tentang peningkatan kualitas produk UMKM Kampung Wisata Bisnis Tegal Waru dalam upaya komersialisasi produk berdaya saing dan berbasis informasi teknologi, perlu keberlanjutan program agar tepat mengenai sasaran sesuai need assesment dan berdampak optimal bagi produsen dalam meningkatkan kompetensi, juga kualitas dan kuantitas produk (Purwaningsih, Muslikh, \& Suhaeri, 2019). Tahun 2019, Desa Tegal Waru terdiri dari 38 RT, 6 RW, dan memiliki jumlah

$\square$ Corresponding Author:

Endang Purwaningsih:

Tel. +62 214206675

E-mail: e.purwaningsih@yarsi.ac.id 


\section{Branding Produk UMKM Kampung Wisata Bisnis Tegal Waru melalui Reputasi Merek...}

Endang Purwaningsih, Suhaeri, Evie Rachmawati Nur Ariyanti

penduduk sebanyak 12.123 jiwa. Terdapat 85 UMKM dan baru terbina 35 UMKM oleh Yayasan Kuntum Indonesia. Sebagian besar masyarakat berprofesi sebagai petani dan wirausaha, setiap RW masyarakatnya memiliki spesifikasi usaha sendiri.

Mengingat permasalahan yang dihadapi mitra sangat kompleks, yakni: belum ada asosiasi/perkumpulan produsen, akses teknologi informasi belum dimanfaatkan, merek produk belum terdaftar sehingga tidak dilindungi hukum, keterbatasan jangkauan pemasaran produk yang belum on-line, dan kompetensi manajemen pemasaran yang masih rendah yang mengakibatkan daya saing produk yang dihasilkan masih rendah, maka Tim Pengusul akan berusaha keras untuk membantu mengatasi permasalahan mitra sesuai kompetensi Pengusul, dengan tetap menggunakan partisipasi aktif mitra dan kerjasama dengan link terkait. Dengan kondisi UMKM yang tata kelolanya masih konvensional, maka dalam rangka meningkatkan kualitas dan kuantitas produk yang berdaya saing UMKM Tegal Waru dari waktu ke waktu perlu dilakukan branding melalui pendaftaran merek, pembuatan perkumpulan dan optimalisasi e-commerce. Branding pada UMKM Tegal Waru terkesan masih belum diakui masyarakat secara luas. Citra merek, simbol/logo dan desain suatu produk dapat dikenal luas dengan adanya branding (Rizaldi \& Putranto, 2018). Branding merupakan cara usaha untuk dapat bersaing secara global yang dapat menghasilkan kesan yang menarik minat konsumen. Mengingat saat ini konsumen tidak hanya mempertimbangkan rasa tetapi juga estetika dari produk yang akan dibeli (Irawan \& Affan, 2020). Branding merupakan aktivitas untuk memberi identitas pada suatu produk dan mempresentasikan atau mengkomunikasikannya agar dapat bertahan dalam jangka waktu yang panjang (Muntazori, Listya, \& Qeis, 2019).

Universitas YARSI dengan multidisiplin dari Magister Kenotariatan Sekolah Pascasarjana (S2), Fakultas Hukum, dan Fakultas Teknologi Informasi, memandang perlu untuk melakukan program pengabdian kepada masyarakat berupa pelatihan dan pendampingan serta fasilitasi berbagai hal di atas bagi pemberdayaan UMKM di Kampung Wisata Bisnis Tegal Waru Bogor.

Berdasarkan analisis situasi, permasalahan yang dihadapi usaha mikro Tegal Waru Bogor dan berbagai prioritas yang perlu dilakukan sebagaimana tampak pada Tabel 1.

Tabel 1. Analisis situasi permasalahan yang dihadapi UMKM Tegal Waru Bogor dan prioritas pendampingan

\begin{tabular}{|c|c|}
\hline Jenis permasalahan & Jenis Pendampingan yang dibutuhkan \\
\hline $\begin{array}{l}\text { Kurangnya pengetahuan terkait legalitas Badan Usaha dan } \\
\text { perkumpulan }\end{array}$ & $\begin{array}{l}\text { Pelatihan dan pendampingan legalitas usaha sampai } \\
\text { terbentuk status badan usaha dan perkumpulan ber akta } \\
\text { notariil atau fasilitasi BUMDES karena BUMDES baru } \\
\text { terbentuk }\end{array}$ \\
\hline $\begin{array}{l}\text { Belum adanya merek UMKM yang terdaftar di Ditjen KI } \\
\text { KemenkumHAM }\end{array}$ & $\begin{array}{l}\text { Pelatihan pembuatan merek dan pendaftaran ke Ditjen KI } \\
\text { KemenkumHAM }\end{array}$ \\
\hline $\begin{array}{l}\text { Kurangnya motivasi dan pengetahuan tentang NIE dan } \\
\text { SIUP }\end{array}$ & Sosialisasi serta edukasi NIE PIRT dan SIUP \\
\hline Belum terlaksananya e-commerce dengan baik & $\begin{array}{l}\text { Pelatihan dan pendampingan optimalisasi pemanfaatan e- } \\
\text { commerce }\end{array}$ \\
\hline Pemasaran konvensional dan kurangnya daya saing & $\begin{array}{l}\text { Peningkatan daya saing melalui tata kelola (manajemen), } \\
\text { strategi pemasaran online dan pembangunan reputasi } \\
\text { merek }\end{array}$ \\
\hline
\end{tabular}


ABDIMAS: Jurnal Pengabdian Masyarakat Universitas Merdeka Malang

Volume 5, No 1, Maret 2020: 60-69

Penetapan prioritas ini dijustifikasi bersama antara mitra dengan tim pengusul melalui beberapa kali pertemuan dan observasi secara langsung. Berdasarkan Tabel 1, dan mengacu pada analisis situasi maka telah diadakan pelbagai kegiatan untuk meningkatkan daya saing produk UMKM. Tim pengusul menentukan permasalahan dengan prioritas tinggi yang telah diselesaikan dalam program ini.

\section{METODE}

Kegiatan yang telah dilakukan adalah pertama, meningkatkan kesadaran dan motivasi UMKM akan arti pentingnya meningkatkan legalitas usaha baik yang bersifat badan usahanya, perkumpulan organisasi maupun legalitas produknya.

Menurut Purwaningsih dkk. (2018) kebanyakan UMKM adalah home industry yang kemudian merangkak menjadi badan usaha dan badan hukum. Kegiatan kedua adalah mendampingi UMKM dalam membuat merek dagang, juga produk UMKM perlu diberikan sertifikasi baik ijin edar (NIE) dan PIRT khusus makanan minuman olahan home industry maupun dalam bentuk perlindungan kekayaan intelektual dalam hal ini utamanya merek. Sistem Hak Kekayaan Intelektual merupakan hak privat (private rights). Seseorang bebas untuk mengajukan permohonan atau mendaftarkan karya intelektualnya atau tidak. Hak eksklusif yang diberikan Negara kepada individu pelaku Hak Kekayaan Intelektual (inventor, pencipta, pendesain dan sebagainya) tiada lain dimaksudkan sebagai penghargaan atas hasil karya (kreativitas) nya dan agar orang lain terangsang untuk dapat lebih lanjut mengembangkannya lagi, sehingga dengan sistem Hak Kekayaan Intelektual tersebut kepentingan masyarakat ditentukan melalui mekanisme pasar (Hastuti, 2019). Menurut Purwaningsih (2015) pendaftaran merek harus dengan iktikad baik karena berhubungan dengan persaingan bisnis dan reputasi pemilik merek.

Pendampingan ini dipilih karena, merek merupakan bagian terpenting dari suatu produk. Merek dapat menjadi nilai tambah suatu produk. Menurut Kotler \& Keller (2009), manfaat merek adalah untuk menyederhanakan penelusuran atau penanganan suatu produk, menawarkan perlidungan hukum bagi suatu perusahaan untuk fitur-fitur atau aspek unik dari suatu produk, merepresentasikan bagian properti hukum yang sangat berharga, sangat mempengaruhi kepercayaan konsumen, dan memberikan keamanan pendapatan untuk masa depan yang lebih langgeng. Merek juga berfungsi untuk membedakan produksi, produk, dan jasa suatu perusahaan dengan perusahaan lain yang sama atau sejenis. Merek menjamin nilai (kualitas) dari produk dan jasa yang bersangkutan, memberi perlindungan dan jaminan kualitas produk dan jasa, sebagai sarana promosi bagi produsen, pedagang, atau perusahaan-perusahaan yang memperdagangkan barang/produk atau jasa, sebagai simbol untuk memperluas pasar, serta merangsang pertumbuhan industri dan perdagangan yang sehat dan menguntungkan semua pihak (Haryadi, 2010)

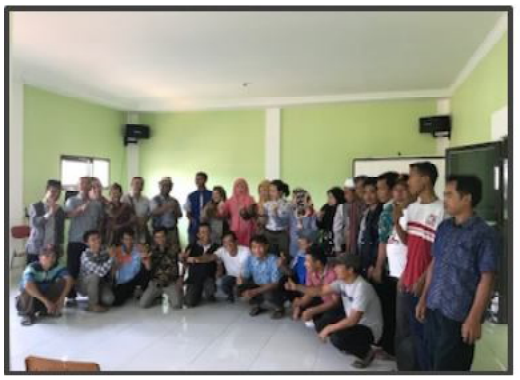

Gambar 1. Sosialisasi pentingnya meningkatkan legalitas usaha

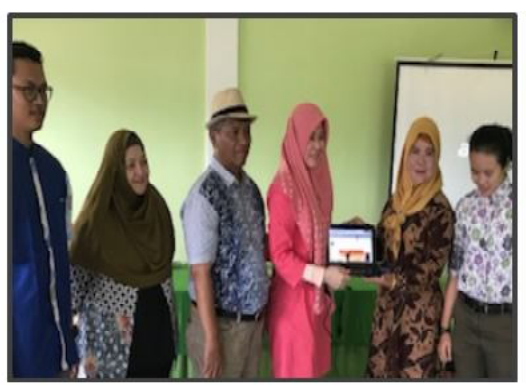

Gambar 3. Penjelasan pelabelan pada produk

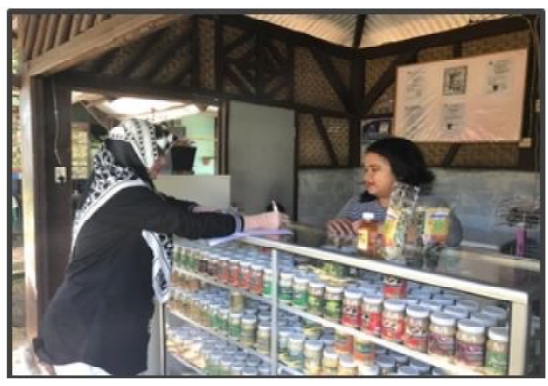

Gambar 2. Penyerahan Sertifikat Ijin Edar 


\section{Branding Produk UMKM Kampung Wisata Bisnis Tegal Waru melalui Reputasi Merek...}

Endang Purwaningsih, Suhaeri, Evie Rachmawati Nur Ariyanti

Ketiga, mengadakan pelatihan-pelatihan dengan materi (1) pelatihan merek dagang dan PIRT; (2) Pelatihan legal entity perkumpulan; (3) Pelatihan desain industri; (4) Tata kelola organisasi dan pembukuan; (5) Menerapkan web-online yang telah dibuatkan Tim; (6) Manajemen web (pengisian konten, operasi web, pemasaran online praktis); (7) Perawatan web.

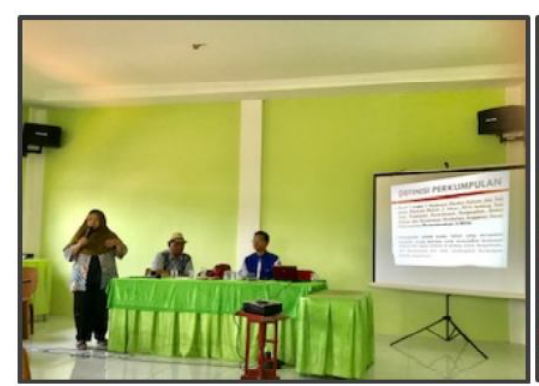

Gambar 5. Pelatihan web

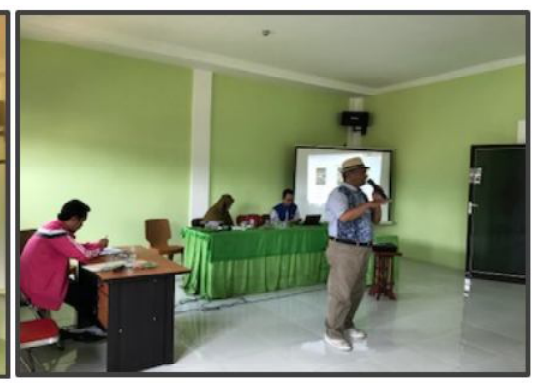

Gambar 4. Pelatihan desain industri

Kegiatan pelatihan peggunaan sistem online dipilih, karena menurut Uzzaman (2015), beberapa keuntungan bisnis online yaitu meliputi: tanpa batas waktu, tanpa batas tempat, efisiensi biaya operasional, kemudahan dalam strategi pemasaran produk, kemudaham manajemen organisasi dan produk, kemudahan pengelolaan kontrol persediaan, kemudahan pengelolaan sumber daya manusia, produktifitas meningkat, (9) memudahkan melakukan riset pemasaran, (10) memberikan keuntungan yang tidak terbatas, dan kemudahan pengawasan. Faktor-faktor ini dianggap sangat mendukung berhasilnya pemasaraan online.

Penelitian yang dilakukan oleh Krishnasari \& Baskoro (2015) yang bertujuan untuk merancang situs e-commerce sebagai sarana pemasaran produk unggulan UMKM Posdaya yang bisa diakses dengan mudah oleh masyarakat, menemukan bahwa untuk nama merek dari sarana pemasaran online sebaiknya memiliki unsur mudah disebut, mudah diingat, dan mudah diketik.

\section{HASIL DAN PEMBAHASAN}

\section{Hasil}

Responden dalam penelitian ini berjumlah 35 pemilik UMKM di Tegal Waru, Kabupaten Bogor. Hasil analisis data berkaitan dengan pemahaman pelaku UMKM tentang minat memiliki merek terdaftar dapat ditabulasikan pada Tabel 2 .

Tabel 2. Distribusi frekuensi Jawaban responden terhadap minat memiliki merek terdaftar

\begin{tabular}{ccccc}
\hline Valid & Frequency & Percent & Valid Percent & Cumulative Percent \\
\hline 2 & 7 & 20.0 & 20.0 & 20.0 \\
3 & 1 & 2.9 & 2.9 & 22.9 \\
4 & 6 & 17.1 & 17.1 & 40.0 \\
5 & 21 & 60.0 & 60.0 & 100.0 \\
Total & 35 & 100.0 & 100.0 & \\
\hline
\end{tabular}

Berdasarkan hasil analisis terhadap data yang terkumpul dapat diketahui bahwa: a) jumlah responden yang tidak berminat memiliki merek terdaftar sebanyak 7 orang $(20 \%)$, b) jumlah responden yang cukup berminat memiliki merek terdaftar sebanyak 1 orang $(2,9 \%)$, c) jumlah responden yang berminat memiliki 
ABDIMAS: Jurnal Pengabdian Masyarakat Universitas Merdeka Malang

Volume 5, No 1, Maret 2020: 60-69

merek terdaftar sebanyak 6 orang $(17,1 \%)$ dan, d) jumlah responden yang sangat berminat memiliki merek terdaftar sebanyak 21 orang $(60 \%)$. Sehingga dapat disimpulkan bahwa mayoritas responden dalam hal ini pemilik UKMK di Tegal Waru, Kabupaten Bogor sangat berminat memiliki merek terdaftar. Untuk lebih jelasnya dapat dilihat pada Gambar 6.

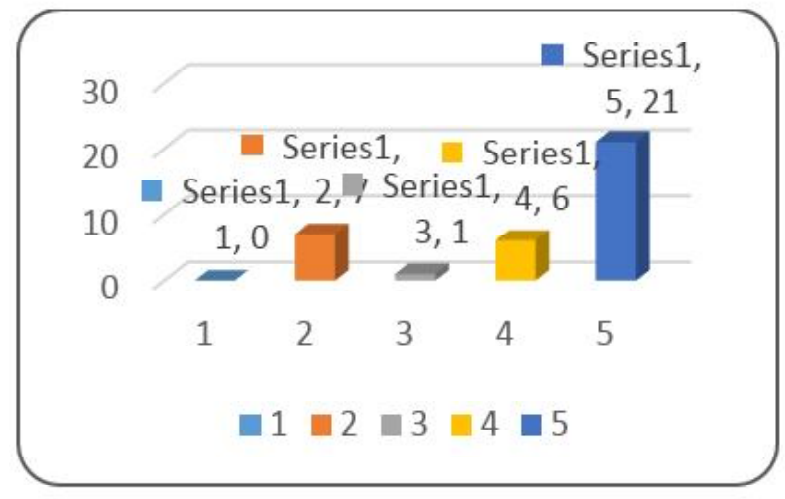

Gambar 7. Distribusi Frekuensi Jawaban responden tentang minat merubah desain produk menjadi lebih bagus

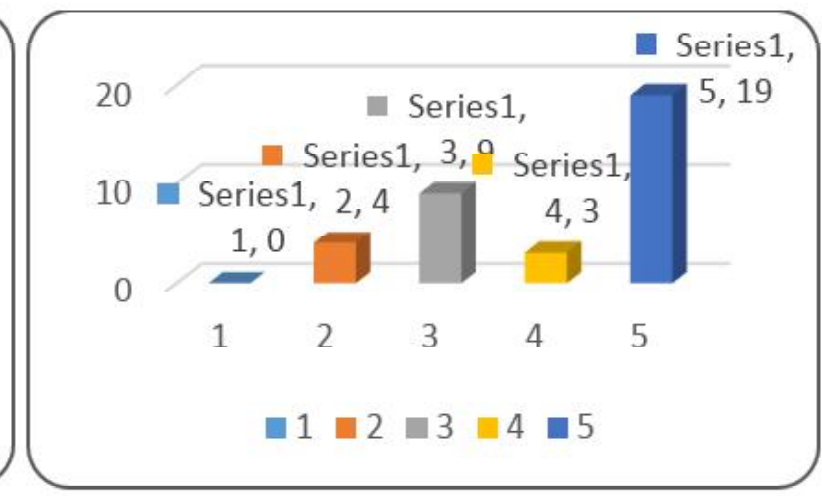

Gambar 6. Distribusi Frekuensi Jawaban responden tentang minat memiliki merek terdaftar

Tabel 3. Distribusi frekuensi jawaban responden terhadap minat merubah desain produk menjadi lebih bagus

\begin{tabular}{ccccc}
\hline Valid & Frequency & Percent & Valid Percent & Cumulative Percent \\
\hline 2 & 4 & 11.4 & 11.4 & 11.4 \\
3 & 9 & 25.7 & 25.7 & 37.1 \\
4 & 3 & 8.6 & 8.6 & 45.7 \\
5 & 19 & 54.3 & 54.3 & 100.0 \\
Total & 35 & 100.0 & 100.0 & \\
\hline
\end{tabular}

Hasil analisis data berkaitan dengan pemahaman pelaku UMKM tentang minat merubah desain produk menjadi lebih bagus dapat ditabulasikan seperti tampak pada Tabel 3.

Berdasarkan hasil analisis terhadap data yang terkumpul dapat diketahui bahwa: a) jumlah responden yang tidak berminat merubah desain produk menjadi lebih bagus sebanyak 4 orang $(11,4 \%)$, b) jumlah responden yang cukup berminat merubah desain produk menjadi lebih bagus sebanyak 9 orang $(25,7 \%), c)$ jumlah responden yang berminat merubah desain produk menjadi lebih bagus sebanyak 3 orang $(8,6 \%)$ dan, d) jumlah responden yang sangat berminat merubah desain produk menjadi lebih bagus sebanyak 19 orang $(54,3 \%)$.

Dapat disimpulkan bahwa mayoritas responden dalam hal ini pemilik UMKM di Tegal Waru, Kabupaten Bogor sangat berminat merubah desain produk menjadi lebih bagus. Uraian penjelasan apabila divisualisasikan dalam bentuk diagram akan tampak pada Gambar 7.

Hasil analisis data berkaitan dengan pemahaman pelaku UMKM tentang minat mendapatkan label halal dapat ditabulasikan pada Tabel 4. 
Branding Produk UMKM Kampung Wisata Bisnis Tegal Waru melalui Reputasi Merek...

Endang Purwaningsih, Suhaeri, Evie Rachmawati Nur Ariyanti

Tabel 4. Distribusi frekuensi jawaban responden terhadap minat mendapatkan label halal

\begin{tabular}{ccccc}
\hline Valid & Frequency & Percent & Valid Percent & Cumulative Percent \\
\hline 2 & 1 & 2.9 & 2.9 & 2.9 \\
3 & 7 & 20.0 & 20.0 & 22.9 \\
4 & 8 & 22.9 & 22.9 & 45.7 \\
5 & 19 & 54.3 & 54.3 & 100.0 \\
Total & 35 & 100.0 & 100.0 & \\
\hline
\end{tabular}

Berdasarkan hasil analisis terhadap data yang terkumpul dapat diketahui bahwa: a) jumlah responden yang tidak berminat mendapatkan label halal sebanyak 1 orang $(2,9 \%)$, b) jumlah responden yang cukup berminat mendapatkan label halal sebanyak 7 orang $(20 \%)$, c) jumlah responden yang berminat mendapatkan label halal sebanyak 8 orang $(22,9 \%)$ dan, d) jumlah responden yang sangat berminat mendapatkan label halal sebanyak 19 orang $(54,3 \%)$.

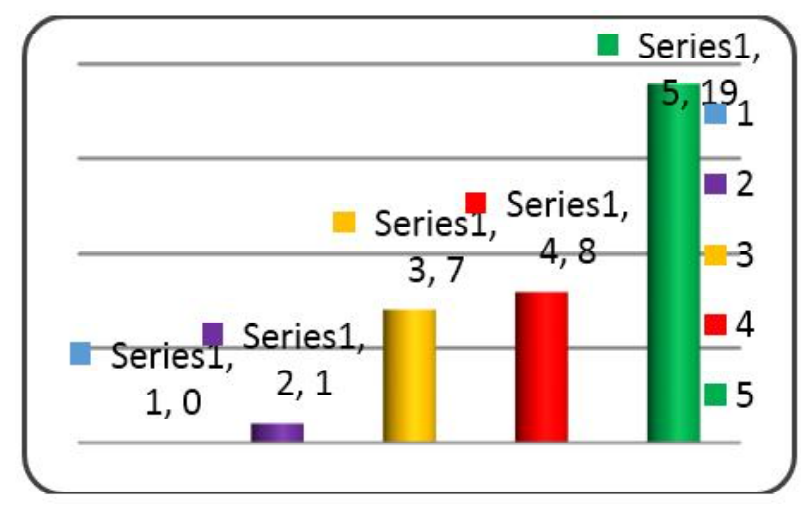

Gambar 9. Distribusi Frekuensi Jawaban responden tentang memaksimalkan pemasaran melalui e-commerce

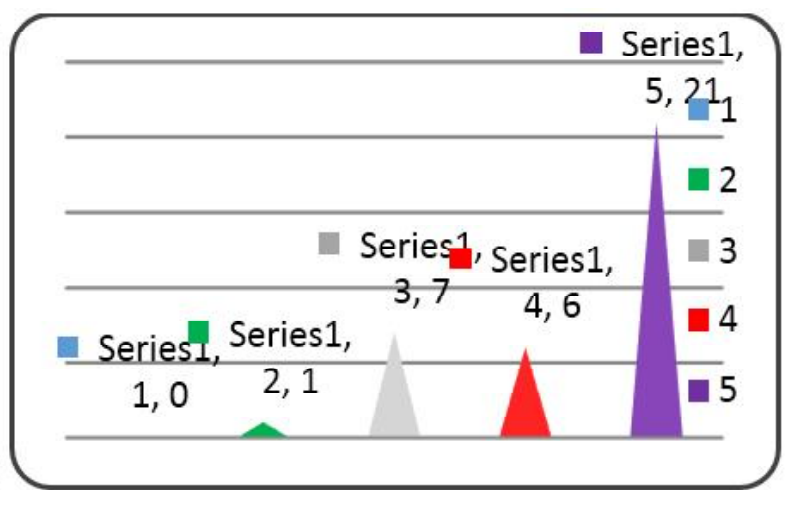

Gambar 8. Distribusi Frekuensi Jawaban responden tentang minat mendapatkan label halal

Sehingga dapat disimpulkan bahwa mayoritas responden dalam hal ini pemilik UKMK di Tegal Waru, Kabupaten Bogor sangat berminat mendapatkan label halal. Apabila uraian di atas digambarkan dalam bentuk diagram tampak pada Gambar 8.

Hasil analisis data berkaitan dengan pemahaman pelaku UMKM tentang minat memaksimalkan pemasaran melalui e-commerce dapat ditabulasikan pada Tabel 5.

Tabel 5. Distribusi Frekuensi Jawaban responden tentang minat memaksimalkan pemasaran melalui e-commerce

\begin{tabular}{ccccc}
\hline Valid & Frequency & Percent & Valid Percent & Cumulative Percent \\
\hline 2 & 1 & 2.9 & 2.9 & 2.9 \\
3 & 7 & 20.0 & 20.0 & 22.9 \\
4 & 6 & 17.1 & 17.1 & 40.0 \\
5 & 21 & 60.0 & 60.0 & 100.0 \\
Total & 35 & 100.0 & 100.0 & \\
\hline
\end{tabular}


ABDIMAS: Jurnal Pengabdian Masyarakat Universitas Merdeka Malang

Volume 5, No 1, Maret 2020: 60-69

Berdasarkan hasil analisis terhadap data yang terkumpul dapat diketahui bahwa: a) jumlah responden yang tidak berminat memaksimalkan pemasaran melalui e-commerce sebanyak 1 orang $(2,9 \%)$, b) jumlah responden yang cukup berminat memaksimalkan pemasaran melalui e-commerce sebanyak 7 orang (20\%), c) jumlah responden yang berminat memaksimalkan pemasaran melalui e-commerce sebanyak 6 orang $(17,1 \%)$ dan, d) jumlah responden yang sangat berminat memaksimalkan pemasaran melalui e-commerce sebanyak 21 orang $(60,0 \%)$. Sehingga dapat disimpulkan bahwa mayoritas responden dalam hal ini pemilik UKMK di Tegal Waru, Kabupaten Bogor sangat berminat memaksimalkan pemasaran melalui e-commerce. Uraian lebih dipahami manakala memperhatikan diagram yang tampak pada Gambar 9.

Berbagai pelatihan telah digelar dan kemudian dilanjutkan dengan pendampingan. Pelatihan dikemas secara praktis dengan mengambil tempat di tempat usaha yaitu balai Desa Tegal Waru, dan telah dilaksanakan pelatihan legal entity perkumpulan, manajemen, ijin edar PIRT, desain industri dan pendampingan merek serta serah terima e-commerce. Hasil kegiatan ini pelaku UMKM Tegal Waru ingin mengoptimalkan peran BUMDES, jadi tidak perlu dibuatkan perkumpulan UMKM, ingin memiliki merek dagang dan melakukan branding dengan e-commerce yang telah diberikan oleh Tim. Diharapkan omzet akan makin meningkat, lebih dari $20 \%$. Pada PKM mono tahun sebelumnya omzet telah naik 20\%, jadi tahun 2019-2020 ditargetkan meningkat hingga $25 \%$.

Berdasarkan hasil wawancara dengan mitra Rara (disetujui oleh sebagian besar UMKM secara aklamasi yang hadir saat pelatihan) bahwa sebenarnya saat ini telah ada BUMDES, maka tidak berminat mengurus perkumpulan, dikarenakan akan banyak membuang tenaga, maka lebih baik dikelola dalam satu wadah BUMDES saja. Demikian pula tentang admin/teknisi IT untuk e-commerce diserahterimakan ke aparat desa, ketua BUMDES Santi telah berkoordinasi dengan aparat desa untuk mengelola dan menyediakan admin demi kepentingan UMKM Tegal Waru. Selain itu, untuk desain industri telah mengubah tikar yang semula sangat sederhana menjadi lebih cantik tampilan dan menambah kualitas menjadi tebal ditambah busa, meskipun dengan harga yang lebih tinggi. Dalam perkembangan pendampingan merek, hanya 2 UMKM yang mendaftar mereknya di Kampung Wisata Bisnis Tegal Waru, namun diharapkan akan memotivasi UMKM lainnya.

Model pemberdayaan telah dibuat dan diajukan sebagai hak cipta atas nama Tim Abdimas, merupakan penyempurnaan draft model PKM tahun 2018 dan riset internal 2018, seperti tampak pada Gambar 10.

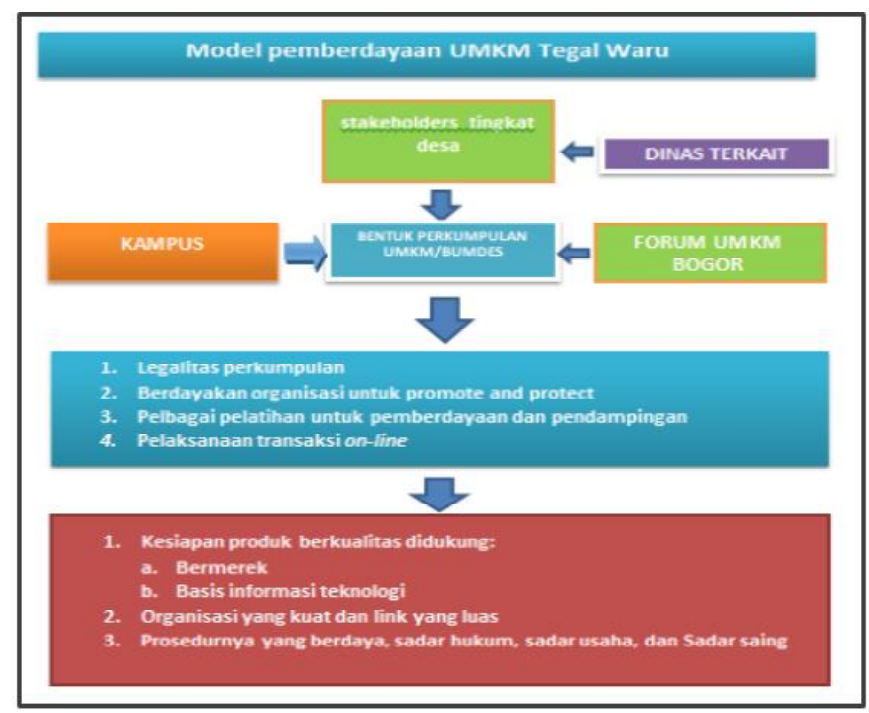

Gambar 10. Model pemberdayaan UMKM Tegal Waru 


\section{Branding Produk UMKM Kampung Wisata Bisnis Tegal Waru melalui Reputasi Merek... \\ Endang Purwaningsih, Suhaeri, Evie Rachmawati Nur Ariyanti}

\section{Pembahasan}

Guna pemberdayaan UMKM Tegal Waru diperlukan peran stakeholders pada tingkat desa yakni aparat desa, produsen, dan organisasi, juga yayasan Kuntum Indonesia yang sejak awal telah membantu produsen. Kemudian forum UMKM dan pemerintah daerah dalam hal ini institusi pemerintahan yang terkait, khususnya Dinas Koperasi-UKM, dan link relevan seperti Dinas Pangan, Pertanian dan Perdagangan dan Perindustrian dalam hal ini sebagai stakeholders tingkat kabupaten yang mendampingi produsen bertugas: (1) melakukan pembinaan, promosi, dan pengembangan SDM, (2) pendampingan dalam memfasilitasi pendanaan dan perluasan pemasaran, (3) melakukan berbagai pemberdayaan dan pendampingan secara terus menerus baik dari sisi kepentingan ekonomi, teknologi, maupun hukum, (4) melakukan edukasi, sosialisasi, perubahan mindset yang mendalam pada produsen tentang pentingnya perlindungan hukum terhadap produknya, pemanfaatan IT untuk branding dengan merek terdaftar, (5) memberikan fasilitasi pembentukan asosiasi produsen UMKM Tegal Waru berbadan hukum (ber-akta notaris).

Asosiasi produsen (UKM) dan atau BUMDES harus mampu mempromosikan dan memlindungi dirinya, bertugas: (1) jika diperlukan membentuk asosiasi berbadan hukum (ber-akta notaris) dalam rangka pelaksanaan pelindungan hukum makanan tradisional berdasarkan UU Merek dan Indikasi Geografis, dan penegakan hukumnya (2) melakukan berbagai kegiatan asosiasi sinergi BUMDES yang dapat mendukung kelancaran pengajuan pelindungan hukum makanan tradisional baik dalam bentuk merek maupun indikasi geografis.

Perguruan tinggi bertugas melakukan: (1) sosialisasi badan usaha dan badan hukum, HKI khususnya peningkatan pemahaman tentang merek dan indikasi geografis, (2) peningkatan pemahaman tentang peraturan perundangan terkait ijin edar (NIE) dan SIUP, (3) peningkatan pemahaman tentang pentingnya pendaftaran merek, indikasi geografis (IG), ijin edar NIE), dan ijin usaha (SIUP), (4) membantu PEMDA memberikan fasilitasi pembentukan asosiasi berbadan hukum (ber-akta notaris), dan (5) pendampingan atau fasilitasi kegiatan mendeskripsikan produk yang diunggulkan untuk pengajuan indikasi geografis.

LSM dan instansi lainnya bertugas: (1) mengulurkan perhatian dan bantuan upaya pelindungan hukum terhadap produk UMKM unggulan Tegal Waru yang mungkin belum diakses oleh perguruan tinggi dan PEMDA, (2) melakukan berbagai kegiatan yang belum dilakukan oleh perguruan tinggi, sebagaimana disebutkan, (3) bekerja sama dengan perguruan tinggi untuk melakukan berbagai kegiatan dalam upaya melakukan perlindungan hukum terhadap produk UMKM Tegal Waru, (4) memberikan penguatan kepada asosiasi produsen, dan (5) membantu peningkatan pemahaman tentang manajemen dan strategi pemasaran untuk branding produk,

Langkah selanjutnya adalah pemerintah daerah bersinergi dengan asosiasi produsen yang tergabung dalam asosiasi UMKM melakukan berbagai kegiatan yang akan memberi dampak terhadap pemberdayaan produsen dan kelancaran proses pengajuan merek atau indikasi geografis. Pemerintah daerah dan Asosiasi Produsen, didampingi oleh perguruan tinggi dan/atau LSM membantu pembuatan organisasi dalam bentuk asosiasi produsen berbadan hukum. Asosiasi atau pemerintah daerah, atau secara bersama-sama inilah yang akan bertindak sebagai subyek hukum yang akan mendaftarkan berbagai jenis produk UMKM tersebut yang diunggulkan untuk mendapatkan pelindungan hukum utamanya merek dagang. Berdasarkan permohonan itu, Ditjen KI KemenkumHAM melakukan berbagai langkah administrasi, mulai dari pengecekan kelengkapan persyaratan administrasi sampai dengan penetapan pelindungan hukum. 
ABDIMAS: Jurnal Pengabdian Masyarakat Universitas Merdeka Malang

Volume 5, No 1, Maret 2020: 60-69

Jadi perlu pemberdayaan masyarakat produsen dalam rangka melindungi produsen dan produknya, keberpihakan pemerintah dan uluran tangan instansi terkait, Dinas Koperasi UMKM, Dinas Perindag, Dinas Pangan, pemerintah daerah, Ditjen $\mathrm{Kl}$, dan perguruan tinggi. Selain itu harus didukung oleh motivasi dari produsen dan organisasi baik organisasi produsen di tingkat Desa Tegal Waru, maupun Forum UMKM Bogor dan yayasan atau LSM yang peduli. Kendala mindset, kekurangan modal, SDM yang rendah kualitas menjadi hal yang perlu dibenahi dengan menerapkan model pelindungan yang telah dihasilkan, di samping juga adanya uluran tangan pemerintah. Jadi rekomendasi kami, perlu sinergitas pemberdayaan masyarakat produsen dan institusi terkait dalam rangka melindungi produsen dan produknya, keberpihakan pemerintah dan uluran tangan instansi terkait, Dinas Koperasi UMKM, Dinas Perindag, Dinas Pangan, pemerintah daerah, Ditjen $\mathrm{KI}$ dan perguruan tinggi.

\section{SIMPULAN DAN SARAN}

\section{Simpulan}

Berdasarkan hasil kegiatan dapat disimpulkan bahwa sebagian besar pemilik UMKM di Tegal Waru, Kabupaten Bogor sangat berminat memiliki merek terdaftar. Selama ini mereka hanya menggunakan merek buatan sendiri yang belum didaftarkan di Ditjen KI Kemenkumham. Mayoritas pemilik UMKM di Tegal Waru, Kabupaten Bogor sangat berminat merubah desain produk menjadi lebih bagus. Mayoritas responden dalam hal ini pemilik UMKM di Tegal Waru, Kabupaten Bogor sangat berminat mendapatkan label halal. Mayoritas pemilik UMKM di Tegal Waru, Kabupaten Bogor sangat berminat memaksimalkan pemasaran melalui e-commerce.

\section{Saran}

Diperlukan keberpihakan aparat desa dan peran BUMDES untuk menerapkan model pemberdayaan agar lebih optimal, beserta Forum UMKM Kabupaten Bogor untuk mendampingi pelaku UMKM di Kampung Wisata Bisnis Tegal Waru Bogor yang digunakan untuk dapat melaksanakan program pengabdian pada masyarakat yang sejenis.

\section{DAFTAR PUSTAKA}

Haryadi, R. E. (2010). Perlindungan Hukum bagi Pemegang Merek terhadap Pelanggaran Merek menurut UU Merek Indonesia. Yuriska : Jurnal IImiah Hukum, 2(1), 124-130. https://doi.org/10.24903/yrs.v2i1.79

Hastuti, I. (2019). Perlindungan Hukum bagi Pemilik Merek Terkenal berdasarkan Undang-Undang Nomor 20 Tahun 2016 tentang Merek dan Indikasi Geografis. Hukum dan Dinamika Masyarakat, 16(2), 174-184. http://dx.doi.org/10.36356/hdm.v16i2.1026

Irawan, D., \& Affan, M. W. (2020). Pendampingan Branding dan Packaging UMKM Ikatan Pengusaha Aisyiyah di Kota Malang. Jurnal Pengabdian dan Peningkatan Mutu Masyarakat (Janayu), 1(1), 32-36. https://doi.org/10.22219/janayu.v1i1.11188

Kotler, P., \& Keller, K. L. (2009). Manajemen Pemasaran Jilid 1. Edisi Ketiga Belas. Terjemahan Bob Sabran. Jakarta: Penerbit Erlangga. 


\section{Branding Produk UMKM Kampung Wisata Bisnis Tegal Waru melalui Reputasi Merek...}

Endang Purwaningsih, Suhaeri, Evie Rachmawati Nur Ariyanti

Krishnasari, E. D., \& Baskoro, M. L. (2015). Perancangan Situs Web Sarana Pemasaran Online Produk UMKM Binaan Posdaya. Jurnal Kesejahteraan Sosial, 2(2), 150-157. https://doi.org/10.31326/jks.v2i02.157

Muntazori, A. F., Listya, A., \& Qeis, M. I. (2019). Branding Produk UMKM Pempek Gersang. Jurnal Desain, 6(3), 177-185. https://doi.org/10.30998/jd.v6i3.4252

Purwaningsih, E., Muslikh, \& Suhaeri. (2019). Peningkatan Kualitas Produk UMKM Kampung Wisata Bisnis Tegal Waru dalam Upaya Komersialisasi Produk Berdaya Saing dan Berbasis Informasi Teknologi. Abdimas: Jurnal Pengebdian Masyarakat Universitas Merdeka Malang, 4(1), 51-57. https://doi.org/10.26905/abdimas.v4i1.3239

Purwaningsih, E., Huda, N., Muslikh, \& Annisariza, N. U. (2018). UMKM Aspek Hukum dan Manajemen Pemasaran Produk. Malang: Empatdua

Purwaningsih, E. (2015). Hukum Bisnis. Bogor: Ghalia

Rizaldi, T., \& Putranto, H. A. (2018). Penerapan Digital Marketing sebagai Strategi Marketing dan Branding pada UMKM. Prosiding, 56-59.

https://publikasi.polije.ac.id/index.php/prosiding/article/view/1186

Uzzaman, B. (2015), Bisnis Pemasaran On-line. Diakses dari http://www.kembar.pro/2015/08/apa-keuntungan-melakukan-pemasaran-secara-online.html. Tanggal 7 Mei 2017. 